\title{
S)
}

ISSN 2278 - 0211 (Online)

\section{Nexus of School Principals' Power Bases and Teachers' Job Satisfaction in Secondary Schools}

\author{
Mengistu Amare Gebreegziabher \\ Lecturer, Department of Educational Planning and Management, \\ Wolaita Sodo University, Ethiopia
}

\begin{abstract}
The aim of this study was to investigate the nexus between school principal power bases and teachers' job satisfaction in secondary schools of Wolaita Zone. A convergent mixed research method was used and a total of 167research participants were participated. Questionnaires and face to face interview were used to collect data. The descriptive result indicated that expert power (3.88) and work (5.04) were found to be the dominant power base and job satisfaction respectively. The correlation results also described that there is a positive link between school principals' legitimate, reward and information power and teachers' job satisfaction. The linear regression analysis result also revealed that legitimate power is the predictor variable of job satisfaction. Hence, from the results of the findings, one can conclude that teachers are more satisfied when school principals apply organizational power bases in secondary schools of Wolaita Zone.
\end{abstract}

Keywords: Iob satisfaction, power bases, school principals, secondary education, teachers

\section{Introduction}

\subsection{Back-ground of the Study}

Power has been a debate of many scholars in the field of management, organizational behavior since 1959 and has been practiced in different geographical settings. As a result, different conceptualization and definitions have been given by several philosophers, politicians, and scholars for the last decades. Scholars classify this flexible concept in many ways. One concise way to classify the different sources of a person's power is to classify as either primarily personal or organizational (Goethals, Sorenson \& Burns, 2004). Besides, French and Raven also classify power bases as reward, legitimate, coercive, information, expert and referent power. A manager's reward power, coercive power, information power and legitimate power would be more strongly derived from the organization, while expert and referent power would be more personally based. All the above source of powers plays an important role in influencing teachers' job satisfaction (Afza, 2005; Lee \& Low, 2008; Nedaee, Alavi, \& Ramezani, 2012). 'Therefore, understanding how power affects teachers' job satisfaction and student achievement will allow school principals to change or maintain their power bases and to achieve desirable outcomes.

Job satisfaction on the other hand, equally plays a great role to produce knowledgeable, skilled and competent students in educational sectors. Similar to power, it has been an issue of concern for many researchers in the past, mostly because of its link with significant organizational phenomena, such as turnover, absenteeism, productivity, career mobility and organizational effectiveness (Nguni, Sleegers \& Denessen, 2006). As indicated by Spetor (2006), job satisfaction is the most repeatedly inspected variable (Spector, 2008). It has been treated regularly because attitudes and emotional state affect the employees' behavior and, thus, possibly lead to the organization's successes or failures. Therefore, improving the performance of schools will not yield any result if teacher's job satisfaction is ignored. This is because satisfied employees perform better and become more efficient and productive since they are likely to be absent less, show less job stress, stay at work longer. Therefore, examining the nexus between principals' power bases and teachers' job satisfaction is important and timely.

\subsection{Problem Statement}

School principals as educational leaders are required to mobilize the abilities and efforts of the teaching staff to provide an effective educational program. To accomplish this, school principals should have the power to fulfill teachers' job satisfaction and organizational outcomes (Bal, et al., 2008).For this reason, school principals need to understand how power is acquired, know how and when to use it, and be able to anticipate its probable effects. As indicated by Nelson and Quick (2012), the concepts of power and leadership are closely linked. Leaders use power as a means of attaining group goals. In addition, by understanding how power functions in organizations, principals will be better to practice that 
information to be a more successful principal (Nelson \& Quick, 2012). Several scholars regularly determine that the principal is indispensable to attaining greater job satisfaction (Blocker \& Richardson, 1963).

Nowadays, research on power bases and job satisfaction has shown a growing concern of researchers around the globe (Ogunleye, Odebiyi, \& Olaoye, 2013). However, studies on power bases and job satisfaction have shown mixed results. Afza, (2005) and Lee and Low (2008) for example, revealed that referent power, expert power and reward power showed a positive relationship with satisfaction (Ogunleye, Odebiyi, \& Olaoye, 2013). On the other hand, Nedaee, Alavi, K. and Ramezani (2012) suggested that no significant relationship was obtained between the two variables. Nevertheless, Bağcl (2014) has also discovered that, with the exception of coercive power, the rest power bases were related to job satisfaction positively. It was established that reward power was contributing to predict employees' job satisfaction. Ashebir's (2016) study results also indicated that Ethiopian university leaders employed reward and legitimate power (position power) types in leading their institutions. However, Lunenburg (2012) also strengthened that personal power (expert and referent) are related to job performance employees' commitment, and job satisfaction. Similarly, studies by Desta (2014) and Raziq, Maula and Bakhsh (2015) also indicate that a positive link was obtained between teachers' job satisfaction and commitment (Ogunleye, Odebiyi, \& Olaoye, 2013). They also confirmed that age and academic qualification have a strong but negative correlation with job satisfaction. The intrinsic and extrinsic factors affecting teachers' job satisfaction were prioritized. Salary payment scale, recognition, incentives and fringe benefits, and performance were the most dissatisfying factors. According to Neog \& Barua's (2014) findings, salary is the most important factor in influencing job satisfaction of employees. Further analysis of Josanov-Vrgovic and Pavlovic (2014) also showed that factors that affect job satisfaction include the nature of work, working conditions, pay, promotion, supervision, fringe benefits, personality and teacher behavior, demographic factors, interaction with students, teacher autonomy, culture and climate of school and others.

Relating to our context, studies on power bases and job satisfaction are very much limited or not even found. Although numerous studies (Desta, 2014; Ogunleye, Odebiyi, \& Olaoye, 2013; Raziq \& Maula Bakhsh, 2015; Tesfaye, 2014) have been undertaken to explore the causes and the consequences of job satisfaction in organizations, the topic has largely escaped the attention of researchers in Wolaita Zone. As indicated in literature, school leaders have direct impacts on the organizational conditions necessary for teachers to be able to effectively carry out instruction leading to increased student achievement though they are not directly interacting with students as much as teachers do (Tek, 2014). Hence, the study will attempt to propose that effective use of power bases leads to a more satisfying context, which leads to more job satisfaction among teachers. As literature pin points, teacher experiences (training and background) also affect the teacher's classroom behavior, which in turn, affects students 'classroom behavior, and finally, student achievement. In general, this study differs from the previous studies conducted so far in different countries in terms of methodology, study area and level, type of respondents. The study will be conducted on government secondary schools of Wolaita Zone. However, most of the studies conducted so far were done in the business (profit making) organization, hospitals, military camps, industry etc. other than education institutions, particularly in secondary education. Besides, most of the studies conducted to date used quantitative research method to address the issue (Junaimah, See, \& Bashawir, 2015; Mengistu, 2015; Richmond, McCroskey, \& Davis, 1986) whereas this study will try to use mixed research approach to collect both quantitative and qualitative data from the respondents. All the above evidence makes this study different from previous studies. The results of this study therefore, will help to look into the correlations between and among the operational constructs of school leader power bases, and teacher job satisfaction based on empirical evidence. Hence, the following four questions guide the investigation:

- What is the dominant power base in the in secondary schools of Wolaita Zone?

- What is the relationship between school principals' power bases and teachers' job satisfaction in secondary schools of Wolaita Zone?

- What is the correlation between demographic variables (principals' sex, experience, educational level) and teachers' job satisfaction?

- Which power base predicts teachers' job satisfaction in secondary schools of Wolaita zone?

\section{Literature Review}

\subsection{Power Bases in Organization}

The bases of power differ according to the manner in which social changes are exercised, the durability of such changes, and the paths in which each basis of power is established and maintained (Raven, 2012). Several categorizations have been used in differentiating bases of social power in organizations. One way of categorization is classification of power bases into two as personal and position power. For example, Daft (2005) defines position power as the power that comes from holding a particular office, position, or rank in an organization. A University president, for instance, has more power than a college dean of education and behavioral studies, but they both have formal power. Personal power, on the other hand, is the capacity to influence others that comes from being viewed as knowledgeable and likable by followers. This type of power is derived from the interpersonal relationships that leaders develop with followers (Yukl, 2006). Some argue that when leaders have both position and personal power, it is advisable to use more personal power than position power because over employment of position power may minimize the ability of a principal to influence teachers (Goffee \& Jones, 2007). Of course, it is essential to understand when it is more suitable to use position power.

- Coercive power is based on teachers' perception that a principal has the capacity to punish teachers if they fail to follow to his or her influence attempt. Mostly, it is not recommended to use coercive power but when there is unnecessary theft and bad practice, it is likely to use coercive power as a last option. 
- Reward power is based on the assumption that teachers that a principal can reward teachers for desired behavior (Green, 1999). It is heavily depends on the ability of the school principal to provide a type of reward including acknowledgement, promotion, incentives to others (Gale, 2009, Le Roux, 2012; Northouse, 2016) and involves control over desirable resources and rewards (Yukl, 2013).

- Legitimate power is based on the belief of the teachers that a principal has the right to prescribe and control their behavior. It is an official or formal power that is grounded on position in an organization (Yukl, 2013). In a school context, the principal has the right to give orders to teachers using his/ her position he/ she holds (Gale, 2009). Legitimate power is determined by a principal's position in the hierarchy of the school (Schulz \& Teddle, 2001)

- Expert power is based on teachers' belief that a principal has job experience and special knowledge or expertise in a given area. For example, a principal who is knowledgeable about how to lead teachers has expert power. Gale (2009) indicates that expert power can be acquired by demonstrating competence including decision making and imitating changes that lead to success.

- Referent power is based on teachers' interpersonal attraction to and identification with a principal because of their admiration or personal liking of the principal. As Gale (2009) further elaborates that referent power comes from teachers respect for a principal and their desire to understand or imitate a principal. For instance, a school principal who is loved by teachers has referent power (Northouse, 2016).

- Information power involves both the access to vital information and control over its distribution to others. Some access to information results from a person's position in the organization's communication network. Managerial positions often provide opportunities to obtain information that is not directly available to subordinates or peers (Mintzberg, 1973). Some role positions in schools including purchasing, human resource and financing provide access to important information about events in the external environment of an organization.

\subsection{The Concept of Job Satisfaction}

Job satisfaction is one of the areas that has been widely researched and yet one of the complex ones (Lumley, et al., 2011; Mester et al., 2003). Different scholars have tried to define the term job satisfaction in different ways. The most widely accepted definition of job satisfaction is the one who is defined by Sergio, \& Brain (2014) as a pleasurable or positive emotional state resulting from the appraisal of one's job or job experiences. Other scholars also define job satisfaction in similar ways as the degree of pleasure or positive effect that an employee has toward his or her job (Lawrence, 2011); the degree to which subordinates are interested in their work; the discrepancy between workers' expectations and what they actually get (Sattar, Nawaz, \& Khan, 2012); the feelings of employees towards their job (Gull, \& Zaidi, 2012); perceived relationship between what one wants from one's job and what are perceived it as offering (Lound, 2003); the collection feelings and beliefs that employees' have about their jobs (Jones, \& George, 2004); Employees' general attitude towards his or her job (Armstrong, 1999). Armstrong (1999)also added that job satisfaction is considered as the feelings and attitudes of people toward their job. Job satisfaction is maintained if people have constructive and positive feelings towards their job, but if they have unconstructive and negative feelings towards their job, this leads to job dissatisfaction.

Although the above definitions seem a bit different in explanation, the basic themes in them are similar. They all have the ideas of pleasure or positive effect, feelings, general attitudes of people towards their job. In addition, the concept of benefits, promotional opportunities, supervision, work conditions are included in the definitions.

\subsection{Dimensions of Job Satisfaction}

Scholars have tried to devise several job satisfactions dimensions to determine the satisfaction level of people. For example, working conditions, promotions, the nature of the work, benefits, payment etc. determine the satisfaction level of people. In addition to the above factors, Chowdhary (2013) identified factors related to workspaces as having influence on job satisfaction. Such factors include building design, air quality and temperature, noise and lighting and others (Goffee \& Jones, 2007). Other factors mentioned by the researchers are nature of job, working promotional methods, performance appraisal, and relationship with other employees and management, grievance handling and so on. Sowmya and Panchanatham (2011) also identified factors including pay and promotion, coworker behavior, job and working condition, supervisory behavior, and organizational aspect. Other factors are interpersonal relationships among the workers, caring for employees and counseling employees. Factors such as sex, age, education, salary, and experience are found to have an influence on job satisfaction of employees (Goffee \& Jones, 2007).

Spector on the other hand identified nine facets of job satisfaction that determine the satisfaction of employees. The nine factors are pay, promotion, supervision, fringe benefits, contingent rewards, operating conditions, coworker, nature of work and school management (Hamidifar, 2009; Heyliger, 2014; Lumley et al, 2011). For Spector, a facet of job satisfaction is any area that brings about a sense of satisfaction as well as dissatisfaction. Pay is one facet of job satisfaction relates to pay or pay raise of a teachers (Sageer, Rafat, \& Agarwal, 2012). Although money has some credit for humans, having enough may not necessarily mean that the individual is satisfied. However, the results of many studies show that pay can significantly affect the overall job satisfaction of employees (Lumley, et al., 2011;Shaikh, Bhutto, \& Maitlo, 2012). Promotion also refers to the chances for advancements that are made available for subordinates within an organization and gives opportunity for individual progress, further responsibilities and improved social status (Lumley, et al., 2011). This indicates the great importance of promotion for satisfaction of employees (Sageer, Rafat, \& Agarwal, 2012).Supervision relates to the idea that when the immediate supervisor if friendly, praise subordinates, listen to employees' opinions and are more interested in their subordinates, the job satisfaction is more likely to increase (Lumley, et al., 2011). According to the author [59], how supervisors treat their subordinates highly affect the satisfaction of those 
subordinates. Fringe Benefits also refers to both monetary and non-monetary benefits that an organization is ready to offer to its employees. Fringe benefits can be intrinsic or extrinsic. Organizations can increase the commitment and performance of staff by making available fringe benefits that are regarded as important by the staff (Lumley, et al., 2011).Contingent rewards stand for appreciation, recognition and rewards for appropriate work done by the teachers. When teachers feel that they are not rewarded according to their contributions, they are more likely to be dissatisfied leading to low commitment thereby low productivity (Lumley, et al., 2011). Working conditions refers to the policies and procedures used in an organization. Some procedures may be too tight that flexibility is impossible when needed. This may lead to dissatisfaction among the teachers (Lumley, et al., 2011). Teachers become more satisfied when respected (Kumari, 2011). Working condition also refers to the environment in which teachers are working. It gives teachers a feeling of safety, comfort and motivation (Singh \& Jain, 2013). Coworker also relates to having coworkers who are friendly and supportive to each other. Having such co-workers brings satisfaction among the teachers. The reverse will be true if there are no such kinds of coworkers (Lumley, et al., 2011). The nature of the work similarly refers to the type of work done. When teachers are mentally challenged by their work, provided with a variety of tasks and freedom and opportunity to develop their skills and abilities and feedback, they are more likely to be satisfied with their job (Lumley, et al., 2011). The last facet of job satisfaction is communication. Here communication includes both formal and informal communication within the organization. Effectiveness within an organization brings motivation and commitment, thereby resulting in increased job satisfaction (Lumley, et al., 2011). Communication is related to satisfaction both at personal and at the organizational level. Lack of effective communication prevents an organization from achieving its goal (Kumari, 2011).

\subsection{Empirical Researches on Power Bases and Job Satisfaction}

Numerous studies have shown different results regarding the relationship between power base of principals and employee's job satisfaction. For example, Afza (2005) concluded that employee's job satisfaction is positively influenced by reward and referent power bases. Another study by Elangovan and Xie (2000) found that a positive association was obtained between teachers' satisfaction and legitimate referent power and reward. Nadaee et al. (2012) also indicates that, employee's job satisfaction was not correlated withreward power. Referent and expert powers were also seen as important; offices that had managers ranking high in those powers tended to have respondents with higher job satisfaction and better performance (Stichman, 2002). Reward and coercive powers were deemed less important, and both had negative relationships with job satisfaction and performance (Stichman, 2002).

Previous studies also indicated that expert power and referent power are positively related to job satisfaction (Busch 1980; Carson, et al. 1993; Comer 1984; Rahim 1989; Rahim \& Buntzman 1991). Coercive power is negatively linked to satisfaction and performance in some studies (Busch 1980; Comer 1984) and is not associated with satisfaction or performance in others (Rahim 1989; Rahim \&Buntzman 1991). Zemanek (1995) also found that the use of all power bases, except coercive power, was significantly and positively related to customer satisfaction, while coercive power maintained a negative relationship (Stichman, 2002).

In sum, the reviewed studies on the use of power bases and job satisfaction reveal that the power bases are employed in different extents in different situations. However, many study results depicted that personal power bases are closely associated with job satisfaction. In general, to satisfy the need of academic staff, the managers at different echelon of the school should know the appropriate type of power bases considering the context of the school, the link between the agent and the target and the attitude of the influencing agent.

\subsection{Hypotheses to be tested}

- H1: School Principals' legitimate power is positively related to teachers' job satisfaction in secondary schools of Sodo Zuria Woreda

- H2: School Principals' reward power is positively related to teachers' job satisfaction

- H3: School Principals' coercive power is positively related to teachers' job satisfaction

- H4: School Principals' information power is positively related to teachers' job satisfaction

- H5: School Principals' expert power is positively related to teachers' job satisfaction

- H6: School Principals' referent power is positively related to teachers' job satisfaction

- H7: Respondent's sex is positively related to teachers' job satisfaction

- H8: Respondent's academic rank is positively related to teachers' job satisfaction

- H9: Respondent's experience (years of service) is positively related to teachers' job

- H10. Respondent's sex is positively related to power base

- H11: Respondent's academic rank is positively related to power base

- H12: Respondent's experience (years of service) is positively related to power base

\subsection{Theoretical Framework}

Figure 1 shows proposed nexus between school principals' power bases (independent variables) and teachers' job satisfaction (dependent variables). This theoretical framework was developed from literature and findings of different studies. It was basically based on Lee, and Low (2008) power bases and job satisfaction theoretical framework. The model shows that six power bases are related to job satisfaction. The six power bases are expert, reward, coercive, legitimate, referent and expert. It is assumed that each of these power bases are related to job satisfaction of the teachers as measured by pay, promotion, supervision, fringe benefits, contingent reward, co-worker, nature of work, working conditions and school management in a certain way. In this model, power base is regarded as independent 
variable and job satisfaction is taken as dependent variable. Figure 1 shows proposed relationship between power base (independent variable) and teachers' job satisfaction (dependent variable).

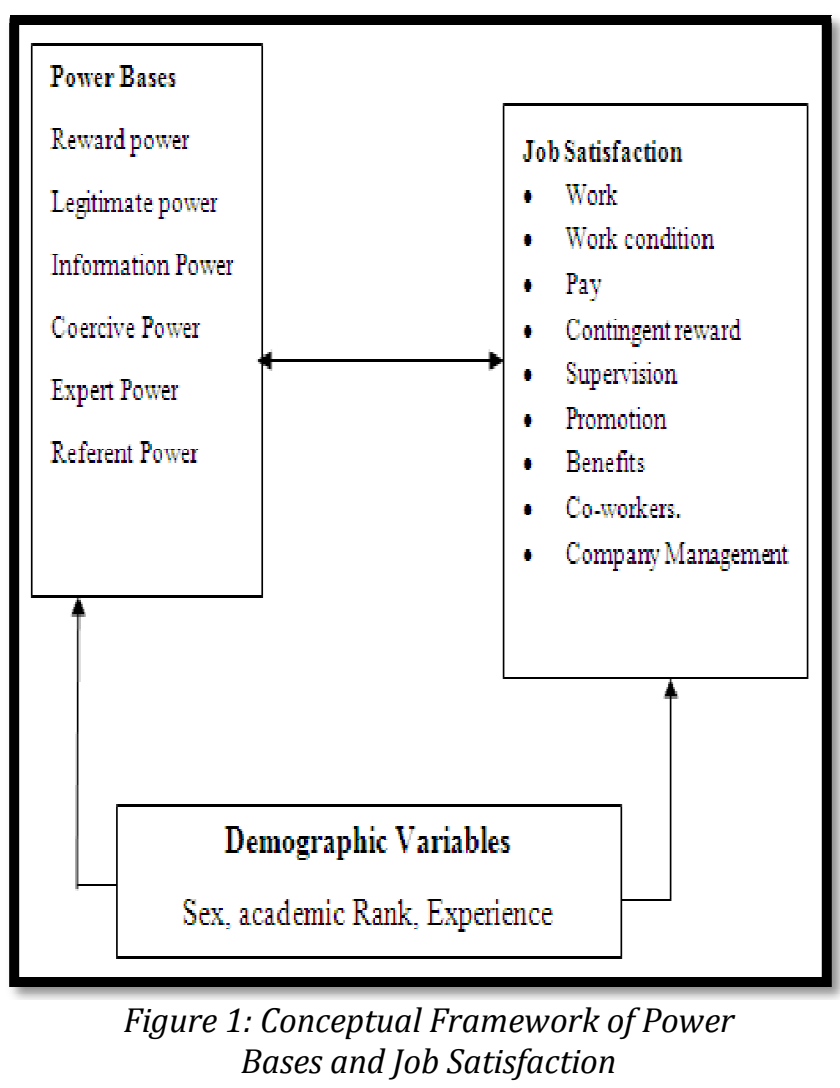

\section{Research Methods and Design}

This study addressed the nexus school principal power base and teachers' job satisfaction. In this study, convergent mixed research was adapted as the general research approach. The quest for triangulation in multiple ways, such as, data collected from multiple sources, multiple approaches of data analysis and interpretation considered as rationales to adapt mixed research approach. In general, using the mixed research methods, qualitative results gave new dimensions to concepts such as perception on bases of power, job satisfaction dimensions, causes of job dissatisfaction, and possible solutions for job dissatisfaction that cannot be captured in quantitative measures/analysis of the concept and vice versa.

The researcher used both primary and secondary sources of data to collect the required data from the research participants. The primary sources of data were teachers, department heads, unit leaders, vice principals and principals. The researcher selected these research participants because he believed that the respondents have adequate and rich information about the topic under study. Besides, they hold different positions and have experience in the schools and various managerial positions including coordinating and managing different programs at various echelons of the school. Thus, they have better interaction with many teachers, so that they know their feelings and views better than any other person. Secondary data were collected through reviewing various sources such as school level demographic data; research reports and statistics data from relevant journals and literatures as well as related issues along the topic of discussions were considered for the purpose of data triangulation;

The population for this study was all teachers and school principals in Wolaita Zone. Three secondary schools were selected using simple random sampling technique. The participants include 152 teachers (out of 165), 6 department heads (out of 12), 3 unit leaders (out of 3) and 6 principals including vice principals (out of 9). A total 167 research participants were taken for this study. Both simple random and purposive sampling techniques were employed to select respondents. Simple random sampling technique was used to select teachers, and department heads whereas unit leaders and school principals were selected purposely.

To collect the required data, standardized questionnaires and face to face interview were used. Two types of standardized questionnaires were used in the study, namely; the Leader Power Inventory (LPI) and Job Satisfaction Survey (JSS). The six French-Raven power bases (legitimate, reward, coercive, expert, information and referent) were measured by the Rahim Leader Power Inventory (RLIP) (Rahim, 1988). This RLIP with 35-items use a 5-point Likert scale to measure the nexus between school principals' powerbases and teachers' job satisfaction. A higher score indicates a greater base of a principal's power. The reliability of LPI was tested many times in different places. It is reported that the reliability of LPI was above 0.70 as indicated in many research works. The current reliability of the instrument was computed and ranges from .71 to .89. This shows that the level of reliability of the questionnaire was acceptable. An alpha level 0.05 is used as the level of significance for this study. The statistical significance of the correlation coefficient can be found and should be 
0.05 or higher if reliability is to be guaranteed Cohen, Morrison and Minion (2005). Therefore, with certain modification the respondents were given this questionnaire to respond the desired data.

Similarly, job satisfaction was taken from Job Satisfaction Survey of Spector (1994). The job satisfaction survey (JSS) is developed by Spector in 1985 with 36 items and six choices ranging from "strongly disagree" to "strongly agree". It is designed to investigate teachers' attitudes about their job(Spector, 1997). The nine facts of job satisfaction were pay, promotion, supervision, fringe benefits, contingent rewards, work, work condition, coworkers, and company/ school management (Lumley, et al., 2011). Raters' were requested to complete a questionnaire regarding their satisfaction about their job. The JSS is self-explanatory and is completed individually (Spector, 1997). The standardized questionnaires were used to collect data from teachers and department heads as it saves time, cost as well as it is easy to administer. The researcher made some modification in some of the questions based on the respondents' response in the pilot test in order to make the questions understandable to research participants. Besides, interview was made with selected teachers, unit leaders, vice principals and school principals face to face to further obtain detailed information about the topic under the study from the research participants.

The reliability of JSS was mentioned by Spector (cited in the author Hamidifar, 2009) to be a Cronbach alpha ranging from 0.60 to 0.82 for all the nine subscales of job satisfaction. Since most facets showed reliability above .70 it gives confidence that there is a good level of reliability.

The data analysis process of this research study was carried out to exactly follow the methodological process that has been described above. The Quantitative Questionnaires were analyzed both using descriptive and inferential statistics. To analyze the demographic characteristics of the respondents, frequency distribution was computed. Then, the data was put in tables and changed to a percentage. Mean and standard deviation were also computed to explore the dominant power base and the satisfaction status of teachers. To investigate the nexus between power base and facets of job satisfaction, correlational analysis was used. To see the relationship between demographic factors (sex, experience, academic rank etc.) and teachers' job satisfaction, correlational analysis was conducted. To allow for prediction of dependent variable, simple linear regression was used as an analysis technique. According to Marczyk, DeMatteo, and Festinger (2005), regression is similar to the correlation in that it examines the relationship between variables. However, it is different from correlation in that its primary purpose is prediction. One of the types of regression is simple regression. In simple regression, the researcher attempts to predict the dependent variable with a single independent variable. In this study, the researcher was interested to examine how much job satisfaction could be predicted by power bases. That means, there was only one independent variable (power base) which was used to predict the dependent variable (job satisfaction).

In addition, SPSS (21.00 version) Software program was also used to produce a detailed analysis of the data in terms of frequency counts, percentages, mean, standard deviation, and correlation depending on the research questions and the specific nature of the data collected to show the average agreements and disagreements of the respondents, to check the existence of statistically significant differences or similarities on the perceptions of the research participants. An alpha level of .05 is used as the level of significance for this study.

The qualitative portion of the study was analyzed using qualitative analysis technique. It enabled the researcher to understand the experiences of the respondents involved in the sampled secondary schools. The purpose of interviewing them in their natural setting was to make them more receptive to narrate in their inner voices and words their experiences concerning power bases and job satisfaction. Once the relevant qualitative information was generated from interviews, the description, classifications, and associations of the information were carried out based on the major themes of power bases and job satisfaction. Such analysis technique was adapted from the work of Bazeley (2009), where he noted the ideas of thematic analysis (three key strategies), including description of data, classification of data, and seeing how concepts interconnect. Therefore, the researcher first described the information as they are, then the categorization of information was conducted based on similarities and difference of the themes. Lastly, the researcher made the connection between and among concepts described and classified in order to have the full picture of the study. The researcher used open code (4.2) software to analyze qualitative data analysis.

\section{Results and Discussion}

\subsection{Results}

\subsubsection{Descriptive Analysis of Job Satisfaction Dimensions}

In the interpretation of the job satisfaction dimensions, the researcher used the absolute approach of Spector (2007). According to the absolute approach method of Specter (2007), scores with a mean item response of 4 or more represents satisfaction, whereas mean response of 3 or less represents dissatisfaction. Mean scores between 3 and 4 are ambivalent (Spector, 2007). Therefore, Table 1 shows the descriptive statistics of job satisfaction dimensions. 


\begin{tabular}{|c|c|c|c|c|c|}
\hline Job Satisfaction Dimension & $\mathbf{N}$ & Minimum & Maximum & Mean & Std. Deviation \\
\hline Work & 151 & 1.20 & 6.00 & 5.04 & .897 \\
\hline Work condition & 150 & 1.00 & 6.00 & 4.38 & 1.189 \\
\hline Payment & 152 & 1.00 & 6.00 & 3.24 & 1.189 \\
\hline Promotion & 152 & 1.00 & 5.00 & 2.98 & .986 \\
\hline Supervision & 151 & 3.00 & 6.00 & 4.67 & .878 \\
\hline Benefit & 151 & 1.00 & 5.00 & 2.69 & 1.169 \\
\hline Contingent reward & 150 & 1.75 & 6.00 & 4.05 & 1.110 \\
\hline Co-workers & 152 & 1.80 & 6.00 & 4.15 & .936 \\
\hline School management & 151 & 2.25 & 6.00 & 4.06 & .922 \\
\hline Valid N (listwise) & & & & & \\
\hline
\end{tabular}

Table 1: Descriptive Analysis of Job Satisfaction of Teachers

Table 1 indicates the means, standard deviations and maximum scores of the job satisfaction dimensions. According to the data in Table 1, the mean score for work (5.04) was found the highest in comparison to the other job satisfaction dimensions. The maximum score was 6 and the minimum was 1 . It was therefore inferred that most of the teachers were satisfied with the work itself. The second job satisfaction dimension which was perceived by many teachers was the supervision with a mean score of 4.67 followed by work condition $(\mathrm{M}=4.38)$, co-workers (M=4.15), school management $(M=4.06)$ and contingent reward $(M=4.05)$. This shows that most teachers obtained satisfaction from the work they engaged, supervision, work condition, co-workers, school management and contingent reward. Benefits were selected by many respondents as the least preferred job satisfaction dimension with a mean score of 2.69 followed by promotion with a mean score 2.98. This therefore indicated that many teachers were dissatisfied below average with the benefits they received within the school and the promotion they obtained. This can cause lack of interest and dissatisfaction among teachers in the workplace. This result is consistent roughly with Neog and Barua finding which explains salary payment scale, recognition, incentives and fringe benefits, and performance were the most dissatisfying factors and ranked from $1^{\text {st }}$ to $4^{\text {th }}$. According to Neog and Barua (2014) findings, salary is the most important factor in influencing job satisfaction of employees. Tesfaye's (2014) study has also strengthened the above idea in that 63.3\% teachers were dissatisfied with their job; however, school performance was declined and below 50\%.

In the interview session, participants were asked to respond to the question "how do principals' see the different job satisfaction dimensions of teachers and they all confirmed that teachers like their profession or job. The principals further reported that the school internal work environment is relatively good as compared to the external one. There are staff rooms, tennis table, and tea club with cheap price and library services. The external environment was found severe and seemed dirty and unhealthy for students. There are bars, 'local drink house' etc. The road, which takes to school, is not suitable to students. In relation to this issue, Raziq and Maula Bakhsh (2015) also found that there is a positive relationship between working environment and employee job satisfaction. When employees work in good working conditions, they are more likely to be satisfied (Sageer, Rafat, \& Agarwal, 2012).With respect to pay, the principals assured that the workload and teachers' salary is not equivalent. In other way, the work and payment are not equivalent as compared to other organization payment scale of the same job. One of the interviewees disclosed that 'my work load and the salary that I earn are not comparable. The salary is not enough and does not consider the teachers' load. Relatively, principals' salary is better as compared to teachers. Particularly salary of beginner and junior teachers were found very low. This makes their life very challenging. They are required to pay a minimum of 1000 ETB for house rent. In addition, they have other expenses including transportation cost, costs related to clothing and food etc. The salary is not sufficient for them to cover all these expenses. They spend all their money for food consumption and house rent. The school atmosphere was found not attractive to keep experienced teachers to stay there. Last year, 8 teachers left their profession because of the low salary. In connection to this, Sageer, Rafat, and Agarwal (2012) indicate that employees are more likely to be satisfied when their salaries are equitable to outsiders who are more in the same industry. Concerning to promotion, the principals had to say this

The promotion opportunities are limited for both teachers and principals. It takes two years for beginner teachers to promote to junior teacher. The amount of money added is very small, not more than 300 ETB. Although the chance to get a promotion is not as such difficult, the increment was found unsatisfactory and minimum.

The principals further disclosed that supervisors are fair for teachers. They have close relationships with teachers. They work in a team spirit and decide together. When they decide, they focus on the work itself rather than the teacher him/ herself. In fact, relationships with supervisor and within the group also affect the job satisfaction of employees. Thus, employees are more likely to be satisfied when they have good relationships with supervisors and other coworkers (Sageer, Rafat, \& Agarwal, 2012). Moreover, the principals confirmed that there are no benefits in their school other than sanitary utilities such as soft, soap, and gown. Rarely, teachers get training opportunity. Furthermore, in the interview principals reported that for best performer teachers, the school always provides reward and recognition ceremony twice per year.

Regarding the coworkers, the principals replied that they have a peaceful and good work relationship with teachers. There is no serious conflict among teachers and principals. Majority of the teachers know their responsibilities and duties properly. Only a few teachers violate the rules and regulations of the school. For those teachers, the school management gives regular advice in advance before punishing them. Three teachers were punished so far and two 
teachers were gotten written warning. Research finding also revealed that employees are more likely to be satisfied when they have a good relationship with supervisors and other coworkers (Sageer, Rafat, \& Agarwal, 2012).

Concerning the school management, the supervisors discovered that the school management is strong and gives immediate response to teachers' request. In this regard, BSC helped them to break the bureaucracy at school level. The school management solves problems related to teachers soon. Of course, there are few issues beyond the control of the school like salary issue; house allowance etc. These issues are difficult to solve at the school level. Recently, the government has started solving teachers' salary and housing problem step by step.

In addition, respondents were asked about the causes of job dissatisfaction. Concerning the causes of teachers' job dissatisfaction, the respondents identified the following major causes for teachers' dissatisfaction: Low salary, low societal respect towards teachers, low teachers' living standard, budget constraint, and students' disciplinary problem, lack of fringe benefits, absence of bonus and incentives package (for example other organizations give bonus to their employees when festivals come). Another cause for teachers' job dissatisfaction is the nature of the work. Teaching is a demanding task which requires performing difficult tasks such as teaching students, preparation in advance; correcting students' paper, filling students' grades etc. Besides, the educational environment is not attractive, and there is weak school and parents' relationship.

With respect to the strategies to alleviate the causes of job dissatisfaction, the following solutions are forward by interviewees to resolve the problem. There should be incentives package for teachers to make them stable and keep them long. Besides, for similar work and educational level, similar payment should be made; Increase teachers' salary as soon as the country's economy permits is very important. Teachers' house, salary increment, transport, and house allowance must be provided for teachers. Another point to be considered is that to increase society's awareness and give due emphasis for the teaching profession. Besides, the society should give a moral value for teachers; strengthen school and parents' relationships; change the psychological make-up of students and creating good governance in schools are among the strategies to address the issues.

\subsubsection{Descriptive Statistics of Power bases}

The results of the descriptive analysis of power bases are presented in Table 2 below.

\begin{tabular}{|c|c|c|c|c|c|}
\hline Variables & $\mathbf{N}$ & Minimum & Maximum & Mean & Std. Deviation \\
\hline Expert Power & 151 & 2.33 & 5.00 & 3.88 & .677 \\
\hline Reward Power & 152 & 1.43 & 5.00 & 3.25 & .909 \\
\hline Referent Power & 152 & 1.20 & 5.00 & 3.76 & .819 \\
\hline Coercive Power & 151 & 1.60 & 5.00 & 3.48 & .961 \\
\hline Legitimate Power & 151 & 1.83 & 4.83 & 3.40 & .812 \\
\hline Information Power & 152 & 2.00 & 5.00 & 3.54 & .626 \\
\hline Valid N (listwise) & & & & & \\
\hline
\end{tabular}

Table 2: Descriptive Analysis of Power Bases

Table 2 indicates the means, standard deviations and maximum scores of power bases. Accordingly, the mean score of expert power (3.88) was the highest mean score in comparison to the other power bases sub-variables. This therefore means that most of the teachers perceived that expert power was exercised in the sampled secondary schools as a dominant power base. According to the data in Table 2, the next power base which was perceived by the teachers was referent power with scored mean of 3.76. This shows that referent power was exercised moderately next to expert power. Although there is a slight mean difference between expert and referent power, they were exercised highly in the study schools. In general, personal power bases (expert and referent) are the dominant power bases in the sampled schools. The reward power base was the least preferred power base of all with a mean score of 3.25. The standard deviation of coercive power base was 961 which is the highest score from the other power base sub-variables.

In relation to the idea raised above, respondents were also asked in face to face interview to respond to the question "which power base you often use?" and MW2, one of the interviewees explained that,

I often use legitimate and expert power in my school. I usually rely myself on the rules and regulations of the school. I sometimes use reward power to motivate my employees. I rarely apply coercive power to take disciplinary action when teachers commit mistakes.

Moreover, MW4 reported that, "I often use expert and referent power. Sometimes I use reward and legitimate power. I never use coercive power until then". Furthermore, MW1 also strengthened the idea raised by MW2 by saying "I often use expert, legitimate and referent power to exercise my power. Sometimes I use reward power to reward my teachers and coercive power to take disciplinary action."MW5 has a special view as compared to other teachers. He said that he often uses reward and coercive power to motivate and punish teachers.

In general, several respondents in the interview reported that they often use expert, referent and legitimate power which are roughly consistent with the results obtained from teachers in the survey questionnaire. Thus, from the interview responses, one can infer that expert, legitimate and referent power are mostly exercised by officials in the schools who hold different positions in the school. Reward power is exercised to some extent. Coercive power was found the least preferred power base of all.

Besides, the interviewees were asked about how school principal exercises the different power bases in their school? And they replied the following responses. Concerning expert power, the principals discovered that they have 
adequate expert knowledge and leadership quality. They have taken the leadership training and education. With respect to reward power, the principals and supervisors had to say this,

Reward is offered for three best achiever teachers twice a year based on the criteria set in BSC. The reward is given both in cash (5000 birr for first achiever teacher, 4000 for second achiever, and 3000 for third ranked teacher) as well as in the form of certificate. However, only a few teachers have got this chance. The chance of getting reward is very limited. Sometimes, there is complaint by teachers

With regard to referent power, the principals in three sampled schools disclosed similar ideas. They reported that they have good personality and confidence on their tasks. They treat people fairly and peacefully and solve problems of the school through discussion. They are also good role models for their teachers and their leadership style is more of democratic. They have good interaction with teachers.

Regarding to principals' coercive power, the school principals stated that most of the time they do not use their coercive power. They believe in discussion first. When teachers repeatedly commit mistakes or absent from class without permission, they will be asked to come up with evidence. If they are not come with evidence, principals punish them using oral warning up to salary reduction/ cut. But principals follow school procedures to do that. First, they handle the case individually, then in school management. Lastly, it will be sent the case to the disciplinary committee. Concerning to principals' legitimate power, the principals reported that they are reasonable for their action. They work based on the civil service rules and regulations. The punishment is fair and take reasonable measures. With respect to principals' information power, they discovered that they have healthy relationships with teachers based on transparency. All information needed for teachers easily accessible for teachers timely. Principals work closely with teachers' representative and share information about training, examination, education opportunity. They post it on the notice board. However, sometimes hiding information is seen on the part of principals as reported by supervisors.

\subsubsection{Correlation Analysis of Power Bases and Teachers' Job Satisfaction}

\begin{tabular}{|l|l|l|l|l|l|l|l|}
\hline & JS & RReP & RRefP & CCP & LLP & IIP & EEP \\
\hline Job Satisfaction & & & & & & & \\
\hline Reward Power & .015 & & & & & & \\
\hline Referent Power &. .098 &. $.722^{* *}$ & & & & & \\
\hline Coercive Power & - &. $.670^{* *}$ &. $.400^{* *}$ & & & & \\
& .349 & & & & & & \\
\hline Legitimate Power &. .243 &. $.711^{* *}$ &. $.717^{* *}$ &. $.528^{* *}$ & & & \\
\hline Information Power &. .168 &. $.498^{* *}$ &. $.593^{* *}$ &. $.295^{*}$ &. $.712^{* *}$ & & \\
\hline Expert Power & - &. $.608^{* *}$ &. $.597^{* *}$ &. $.477^{* *}$ &. $.458^{* *}$ &. $.588^{* *}$ & \\
\hline
\end{tabular}

Table 3: Correlational Analysis of Power Bases and Job Satisfaction

**. Correlation Is Significant at the 0.01 Level (2-Tailed)

Note, Js+ Job Satisfaction, Rep= Reward Power, Refp= Referent Power, Cp=Coercive Power, L $p=$ Legitimate Power, I $=$ Information Power And Ep=Expert Power

A Pearson coefficient correlation was conducted to evaluate the relationship between power bases and job satisfaction. Accordingly, the data indicated in table 3 revealed that there was a positive correlation between legitimate power and job satisfaction $(\mathrm{r}=0.243)$. However, the correlation strength was found low between the two variables. Thus, hypothesis 1 was supported. Likewise, a positive association was obtained between information power and job satisfaction, and so do reward power and job satisfaction, but the correlation was not significant $(r=0.168$; $r=0.015)$. Hence, hypothesis 2 and 4 were supported. On the other hand, there was negative correlation among expert, and coercive power and teachers' job satisfaction ( $\mathrm{r}=-.124$; and-.349 respectively). Thus, hypothesis 3 , and 6 were not supported. On contrary, no correlation was found between referent power and teachers' job satisfaction ( $\mathrm{r}=-.098)$. Therefore, hypothesis 5 was not supported.

\begin{tabular}{|c|c|c|c|}
\hline Power Base & Sex & $\begin{array}{c}\text { Academic } \\
\text { rank }\end{array}$ & Experience \\
\hline Power Base & & & \\
\hline Sex & $.454^{*}$ & & \\
\hline Academic rank & .016 & .073 & \\
\hline Experience & -.135 & -.037 & $.755^{* *}$ \\
\hline
\end{tabular}

Table 4: Correlation Analysis between Demographic

Variables and Power Bases

*. Correlation Is Significant at the 0.05 Level (2-Tailed)

A Pearson coefficient correlation was also conducted to evaluate the relationship between demographic variables (Sex, Academic Rank and Service) and power base. Accordingly, the data indicated in table 5, there was a statistically positive correlation between sex and power base $(r=0.454 ; r=.016)$. The correlation strength was found medium between sex and power base, but weak between academic rank and power. However, no correlation was found between academic 
rank and power base $(\mathrm{r}=0.016)$. On the other hand, there was a negative association between teachers' experience and power base(r=-.135). This implies that as experience of the teachers' increases, the correlation with power base becomes negative.

\begin{tabular}{|c|c|c|c|}
\hline & Sex & Academic Rank & Experience \\
\hline Job Satisfaction & & & \\
\hline Sex & -.022 & & \\
\hline Academic rank & -.065 & .039 & \\
\hline Experience & -.146 & -.056 & $.741\left(^{* *}\right)$ \\
\hline
\end{tabular}

Table 5: Correlation Analysis between Demographic Variables and

Job Satisfaction

** Correlation Is Significant at the 0.01 Level (2-Tailed)

Note, JS = Job Satisfaction

A Pearson coefficient correlation was also conducted to evaluate the relationship between demographic variables (Sex, Academic Rank and Service) and Job satisfaction. Accordingly, the data in table 5 indicates that there was a statistically negative and weak correlation between experience and job satisfaction( $\mathrm{r}=-.146)$. This implies that as experience increases, teachers' job satisfaction decreases. However, no correlation was found between sex and job satisfaction as well as between academic rank and job satisfaction.

\subsubsection{Regression Analysis}

The results of the regression analysis of the dependency of the independent variable over the dependent variables are presented in Table 6 below.

\begin{tabular}{|c|c|c|c|}
\hline $\begin{array}{c}\text { Explanatory } \\
\text { Variable }\end{array}$ & Coefficients & $\begin{array}{c}\text { T- } \\
\text { statistics }\end{array}$ & $\mathbf{P}$ \\
\hline Expert Power & .251 & 1.165 & .251 \\
\hline Reward Power & .419 & 1.866 & .000 \\
\hline Referent Power & -.255 & -1.129 & .266 \\
\hline Coercive Power & -1.094 & -5.127 & .000 \\
\hline Legitimate Power & .548 & 2.378 & .022 \\
\hline Information Power & .013 & .066 & .948 \\
\hline
\end{tabular}

Table 6: Simple Linear Regression Analysis of Power Bases Dimensions and Job Satisfaction

Correlation Is Significant at the.001 Level (2 Tailed) Adjusted $R^{2}=.327$

Simple linear regression was applied to see to what extent power base dimensions independently predict job satisfaction. Pertaining to the linear regression analysis between expert power and job satisfaction, the results show the coefficients for expert power was $\beta 1=0.251, t=1.165$, $p$-value $=.251$. This suggests that the change in expert power by one unit can increase job satisfaction by .251 keeping other things constant. Likewise, the linear regression analysis between reward power and job satisfaction, the result shows the coefficient for reward power was $\beta 1=0.419, t=1.866, p$ value $=.000$. This suggests that the change in reward power by one unit can increase job satisfaction by .419 keeping other things constant. Therefore, one can conclude that reward power is positively and significantly contributing to predicting job satisfaction. In contrary, regarding the linear regression between referent power and job satisfaction, the results indicate that the coefficients for referent power was $\beta 2=-.255, t=-1.129$, $p$-value $=0.266$. This shows that one unit change in referent power can decrease job satisfaction by -.255 , keeping other things constant. It is possible to conclude that referent power is negatively contributing to predict organizational commitment. Regarding the linear regression between coercive power and job satisfaction, the results indicate that the coefficients for coercive power was $\beta 2=-1.094, t=-5.127$, $\mathrm{p}$-value $=0.000$

This shows that one unit change in coercive power can decrease job satisfaction by -1.094, keeping other things constant. Regarding the linear regression between information power and job satisfaction, the results indicate that the coefficients for information power was $\beta 2=.013, \mathrm{t}=.066$, $\mathrm{p}$-value $=0.948$. This shows that one unit change in information power can increase job satisfaction by .013, keeping other things constant. Regarding the linear regression between legitimate power and job satisfaction, the results indicate that the coefficients for legitimate power was $\beta 2=.548, t=2.378$, $\mathrm{p}$-value $=0.002$. This shows that one unit change in legitimate power can increase job satisfaction by .548 , keeping other things constant. In general, it was found that both legitimate power and reward power significantly contributed to predict job satisfaction. Jointly, power base dimensions explained $32.7 \%$ of the variation in job satisfaction in secondary schools.

\subsection{Discussion}

The major concern of the study was to examine the nexus between school principals' power base and teachers' job satisfaction in secondary schools of Wolaita Zone. The correlation results indicate that a positive link was identified between school principal's legitimate, reward and information power and teachers' job satisfaction. This result is 
consistent to some extent with the work of Elangovan, and Xie (1999), who had found a positive correlation between employees' satisfaction and reward, as well as legitimate power. Afza (2005) discovered that reward and referent power bases are related with employee's job satisfaction. On the other hand, Nedaee, Alavi, and Ramezani (2012) also found that there is no correlation between the two variables. This indicates that school principals in the study secondary schools exercise more or less organizational power. However, the correlation strength was found low between school principal's power bases and teachers' job satisfaction. In addition, the correlation finding, disclosed that there is a positive correlation between respondents' sex and school principals' power base while negative correlation between respondents' work experience and school principals' power base. This finding was partially inconsistent with Ghafoor's (2012) result which says increase in rank, qualification and salary resulted in an increased job satisfaction. In addition to this, staff with PhD's degrees is more satisfied than the staff with lower degrees (Ghafoor, 2012). Thus, hypothesis 10, 11 and12 were not supported.

The second major focus of the study was on the effectiveness of the five power bases on teachers' job satisfaction. The descriptive result also revealed that the mean score of expert power (3.88) was found the highest of all power bases. This therefore, means that most of the staff members perceived that the expert power was found the dominant power base in the sampled schools as compared to the other power sources. Although there is a slight mean difference between expert and referent power, both are the most effective and dominant power bases in the study schools. As Raven's (1974) found out, the exercise of referent power tends to encourage a more satisfied, cooperative and prolonged relationships between principals and teachers. In a place of work, an individual with attraction often makes every person feel good, so he or she inclines to have a lot of influence (French, Raven, \& Cartwright, 1959;McKenna, 2000).

The descriptive analysis of job satisfaction also discovered that, the mean score for the work (5.04) was the highest in comparison to the other job satisfaction dimensions. It was therefore, inferred that most of the teachers were satisfied with the work they engaged in. According to Raven (2008), job satisfaction is associated with how good peoples' personal expectations at work, are aligned with outcomes. Besides, teachers were satisfied with supervision, contingent reward, school management. The actual quality of management at institutional level has been shown to have a direct impact upon staff motivation. Hutchings, et al., (2000) found that 40 percent of demotivated teachers in London schools cited 'poor management' as being central to their demotivation and dissatisfaction. It is evident that the satisfaction level of any person with his/her job can be measured with different dimensions such as the nature of the work, availability of fringe benefits, reward, promotion, pay etc. The unavailability of these factors in adequate manner may contribute to teachers' dissatisfaction. Adjusted $\mathrm{r}^{2}$ result also indicated that legitimate power was a significant predictor of teachers' job satisfaction. On the other hand, coercive power was the least correlated with job satisfaction. A principal who uses the coercive power brings about transformation by intimidating a teacher who does not follow the principal order(Raven, 2012). It is very important where and in what circumstances can we use the different power sources. For instance, power base which may be effective for one manager may not work for a different leader and follower. It is reasonable to conclude that a leader who is more aware of a variety of alternatives in social power strategies will be most successful and effective (Raven, 2012).

\section{Conclusion}

Leaders use various power bases to influence subordinates so as to achieve organizational goals. In general, the results of this study concerning the relationship of principals' power bases on teachers' job satisfaction were quite consistent with the five hypotheses. Accordingly, the results supported the proposed hypothesis H1, H2, H4, H10 and H12 while H3, H5, H6, H7, H8, H9 and H11 were not supported the proposed hypotheses. The supported results of the hypotheses revealed that teachers are more satisfied when principals often exercise more or less organizational power base. Hence, from the results of the findings, one can conclude that the teachers are more satisfied when school principals use organizational power base.

\section{Acknowledgements}

I would like to express my sincere and heart-felt thanks to my Jeilu Omer (PhD) for his unreserved constructive professional comments. Besides, my special regards goes to secondary school teachers, principals and vice- principals, and supervisors who have devoted their precious time to share their incalculable ideas through questionnaire and interview.

\section{References}

i. Afza, M. (2005). Superior-subordinate relationships and satisfaction in Indian small business enterprises. Vikalpa, 30(3), 11.

ii. Ashebir, B. (2016) Power distance and leadership behavior influence on organizational performance of public higher education institutions of Ethiopia. A Doctoral dissertation, Addis Ababa University, Ethiopia, unpublished.

iii. Armstrong, M. (1999). Human resource management practice. London: KoganPage

iv. Ayral, M., Ozdemir, N.,Findık, L. Y., Ozarslan, H., \&Unlu, A. (2014). The relationship between the students' achievement of Turkish language class and the central exam score. Procedia -Social and Behavioral Sciences, 143, $721-725$

v. Bağcl, Z. (2014). The Effect of Job Satisfaction of Employee on Task and Contextual Performance. Journal of Management and Economics Research, 6, 58-72.

vi. Bal, P. M., De Lange, A. H., Jansen, P. G., \& Van Der Velde, M. E. (2008). Psychological contract breach and job attitudes: A meta-analysis of age as a moderator. Journal of vocational behavior, 72(1), 143-158. 
vii. Bazeley, P. (2009). Analysing qualitative data: More than 'identifying themes'. Malaysian Journal of Qualitative Research, 2(2), 6-22.

viii. Belias, D., \&Koustelios, A. (2014). Transformational leadership and job satisfaction in the banking sector: A review. International Review of Management and Marketing, 4(3), 187.

ix. Bernstein, D. A., \& Nash, P. W. (2008). Essentials of psychology (4th ed.). Boston: Cengage Learning. Retrieved from http://books.google.com/books?id=4Do-bFrt9tUC.

X. Blocker, C. E., \& Richardson, R. C. (1963). Twenty-five years of morale research: A critical review. Journal of Educational Sociology, 36(5), 200-210.

xi. Chowdhary, B. (2013). Job satisfaction among bank employees: An analysis of the contributing variables towards job satisfaction. International Journal of Technology Enhancements and Emerging Engineering Research, 2(8), 1120.

xii. Cohen, Morrison and Minion, (2005). Research methods in education (5 ${ }^{\text {th }}$ ed.). Tayler and Francis eLibrary.www.eBookstore.tandf.co.uk

xiii. Daft, R. L. (2005). The leadership experience, 3rd ed. Mason, OH: Thomson, South-Western

xiv. Dereje, M.S(2014). Teaching staff turnover and its relationship with school management and students' academic performance in secondary schools of South West Shoa Zone, M.A thesis, Addis Ababa University, Ethiopia, unpublished

xv. Desta, A. (2014) Teachers' job satisfaction and commitment in general secondary schools of Hadiya Zone, in Southern Nation Nationalities and People of Regional state. M.A thesis, Jimma University, Ethiopia, unpublished

xvi. Education Strategy Center (ESC) (2016). Analysis of teacher demand and supply of the general education sector in Ethiopia: Magnitude, determinant factors and possible remedies. Addis Ababa, Ethiopia

xvii. Elangovan, A. R., \& Xie, J. L. (1999). Effects of perceived power of supervisor on subordinate stress and motivation: The moderating role of subordinate characteristics. Journal of Organizational Behavior, 359-373.

xviii. French, J. R., Raven, B., \& Cartwright, D. (1959). The bases of social power. Classics of organization theory, 311320.

xix. Ghafoor, M. (2012). Role of Demographic Characteristics on Job Satisfaction. Far East Journal of Psychology and Business, 6(1).1-18

xx. Goffee, R., \& Jones, G. (2007). Leading clever people. Harvard business review, 85(3), 72.

xxi. $\quad$ Green, R. D. (1999). Leadership as a function of power. Proposal Management, 8, 54-56.

xxii. Goethals, G. R., Sorenson, G. J., \& Burns, J. M. (Eds.). (2004). Encyclopedia of leadership: AE (Vol. 1). Sage Publications

xxiii. Gull, S., \& Zaidi, A. A. (2012). Impact of Organizational Politics on Employees' Job Satisfaction in the Health Sector of Lahore Pakistan. Interdisciplinary Journal of Contemporary Research in Business, 4(2), 157-160.

xxiv. Hamidifar, F. (2009). A study of the Relationship between Leadership Style and Employee Job Satisfaction of Islamic Azad University. Tehran, Iran, pp: 45-57.

xxv. Heyliger, W. (2014). Academic administrator leadership styles and the impact on faculty job satisfaction.

xxvi. Hutchings, M., Menter, I., Ross, A., Thomson, D. \& Bedford, D. (2000)Teacher supply and retention in London 1998 - 99: a study of six London boroughs(London, Teacher Training Agency).

xxvii. Jones, G.R. \& J.M. George, (2004). Essentials of contemporary management. McGraw Hill Companies, Inc., Boston

xxviii. Josanov-Vrgovic, I. \& Pavlovic, N. (2014). Relationship between the School Principal Leadership Style and Teacher's Job Satisfaction in Serbia. Montenegrin Journal of Economics, 10 (1). 43-57

xxix. Junaimah, J., See, L. P., \& Bashawir, A. G. (2015). Effect of Manager's Bases of Power on Employee's Job Satisfaction: An Empirical Study of Satisfaction with Supervision. International Journal of Economics, Commerce and Management, 3(2), 1-14.

xxx. Knox, J. A., \& Anfara Jr, V. A. (2013). Understanding job satisfaction and its relationship to student academic performance. Middle School Journal, 44(3), 58-64.

xxxi. Kotter, J. P. (1982). The general managers. New York: the Free Press.

xxxii. Kumari, N. (2011). Job Satisfaction of Employees at the Workplace. European Journal of Business and Management, 3(4), Retrieved May 082015 http://www.iiste.org

xxxiii. Lawrence, J. (2011). Job Satisfaction. The Career Key. Retrieved April,2014 fromhttp://www.careerkey.org/asp/career_options/job_satisfaction.html.

xxxiv. Lee, K. L., \& Low, G. T. (2008). Bases of Power and Subordinates' Satisfaction with Supervision--The Contingent Effect of Educational Orientation. International Education Studies, 1(2), 3-13.

xxxv. Lound, D.B. (2003). Organizational culture and job Satisfaction. Journal of Bus. Ind. Market., 18:21-236.

xxxvi. Lumley, E. J., Coetzee, M., Tladinyane, R., \& Ferreira, N. (2011). Exploring the job satisfaction and organizational commitment of employees in the information technology environment. Southern African Business Review, 15(1).

xxxvii. Lunenburg, F. C. (2012). Power and leadership: an influence process. International journal of management, business, and administration, 15(1), 1-9.

xxxviii. Marczyk, G., DeMatteo, D., \& Festinger, D. (2005). Essentials of research design and methodology. John Wiley \& Sons Inc.

xxxix. McKenna, E. F. (2000). Business psychology and organizational behaviour: a student's handbook. Psychology Press.

xl. Mengistu, A. (2015). The influence of leaders' power bases on academic staff' job satisfaction: The Case of Wolaita Sodo University. International Journal of Innovative Research and Development. 4(5) 1-15. 
xli. Meskill, M. et al (1999). Managerial disturbance handling: a case-study approach. Journal of Managerial Psychology, 14(6), 443-454.

xlii. Mester, C., Visser, D., Roodt, G., \& Kellerman, R. (2003). Leadership style and its relation to employee attitudes and behavior. South Africa Journal of Industrial Psychology, 29(2).

xliii. Mintzberg, H. (1973). The Nature of Managerial Work. New York: Harper Row as cited in

xliv. MoE (2015). Education statistics annual abstract. Addis Ababa, Ethiopia

xlv. Mwamwenda, T. S. (1995). Job satisfaction among secondary school teachers in Transkei. South African Journal of Education, 15(2), 84-87.

xlvi. Nedaee, T., Alavi, K. and Ramezani, Z. N. (2012). Employees' effectiveness. World Applied Sciences Journal, 18 (10), pp.1400-1411.

xlvii. Nelson, D. L., \& Quick, J. C. (2012). Understanding organizational behavior (4th Ed.). Mason, OH: SouthWestern/Cengage Learning

xlviii. Neog, B. B., \& Barua, M. (2014). Factors Influencing Employee's Job Satisfaction: An Empirical Study among Employees of Automobile Service Workshops in Assam. The SIJ Transactions on Industrial, Financial \& Business Management (IFBM), 2(7).

xlix. Nguni, S., Sleegers, P., \& Denessen, E. (2006). Transformational and transactional leadership effects on teachers' job satisfaction, organizational commitment, and organizational citizenship behavior in primary schools: The Tanzanian case. School effectiveness and school improvement, 17(2), 145-177.

1. Ogunleye, P. O., Odebiyi, I. I., Olaoye, B. O. (2013). Exploring the Relationship between Job Satisfaction Dimensions and Organizational Commitment among Nigerian Banks Employees. International Journal of Academic Research in Economics and Management Sciences, 2(6), 85.

li. Platis, C., Reklitis, P., \& Zimeras, S. (2015). Relation between job satisfaction and job performance in healthcare services. Procedia -Social and Behavioral Sciences, 175, 480 -487.

lii. Rahim, M. A. (1988). The development of a leader power inventory. Multivariate Behavioral Research, 23(4), 491503.

liii. Rajasekar, D. \& Bhuvaneswari, K. (2014). An empirical evaluation on job satisfaction of employees towards Chennai Logistics Sector. Indian Journal of Applied Research, 4(2).

liv. Raven, B.H. (2012). Power, six bases of power. Encyclopedia of leadership. Ed. Thousand Oaks, CA: SAGE, $1242-49$.

lv. Raven, B. H. (2008). The bases of power and the power/interaction model of interpersonal influence. Analyses of Social Issues and Public Policy, 8(1), 1-22.

lvi. Raven, B. H. (1974). The comparative analysis of power and power preference. Perspectives on social power, 172198.

lvii. Raziq, A., Maula Bakhsh, R. (2015). Impact of work environment on job satisfaction. Procedia Economics and Finance, 23, 717-725.

lviii. Richmond, V. P., McCroskey, J. C., \& Davis, L. M. (1986). The relationship of supervisor use of power and affinity-seeking strategies with subordinate satisfaction. Communication Quarterly, 34(2), 178-193.

lix. Sageer, A., Rafat, S. \& Agarwal, P. (2012). Identification of variables affecting employee satisfaction and their impact on the organization. IOSR Journal of Business and Management (IOSR-JBM), 5(1), 395-407.

lx. Sattar, A., Nawaz, A., \& Khan, S. (2012). The contextual impacts on job satisfaction of employees in the developing states like Pakistan. Universal Journal of Education and General Studies, 1(2), 072-083.

lxi. Sergio, A.C.\& Brain, F. R. (2014). Job satisfaction. https://wikispaces. psu.edu/display/ psyc $484 / 11 . \quad$ job satisfaction, Accessed in Apr,2014.

lxii. Shaikh, M. A., Bhutto, N. A., Maitlo, Q. (2012). Facets of job satisfaction and its association with performance. International Journal of Business and Social Science, 3(7).

lxiii. Singh, J. K., \& Jain, M. (2013). A study of employees' job satisfaction and its impact on their performance. Journal of Indian research, 1(4), 105-111.

lxiv. Sowmya, K. R., \& Panchanatham, N. (2011). Factors influencing job satisfaction of banking sector employees in Chennai, India. Journal of law and conflict Resolution, 3(5), 76-79.

lxv. Spector, P. E. (1994). Job satisfaction survey. Tampa, Florida: Department of Psychology, University of South Florida.

lxvi. Spector, P. E. (1997). Job satisfaction: Application, assessment, causes, and consequences (Vol. 3). Sage publications

lxvii. Tek, B. A. An investigation of the relationship between school leadership, teacher job satisfaction, and student achievement. A doctoral dissertation, University of Rhode Island, 2014.

lxviii. Tesfaye, J. (2014) Teachers' job satisfaction and school performance in government schools of Lagatafo Lagadadi Administrative Town. M.A Thesis, Haramaya University, Ethiopia, unpublished

lxix. $\mathrm{Vu}, \mathrm{P}$. A. The influences of classroom characteristics and teacher-student relations on student academic achievement. A Doctoral dissertation, University of Maryland, USA, 2009

lxx. Wong, H. K. (2001). There is only one way to improve student achievement. Retrieved from New Teacher website http://newteacher. com/upapers/index. html.

lxxi. Yukl, G.A. (2006). Leadership in organizations. (6th ed.). London: Prentice Hall. 